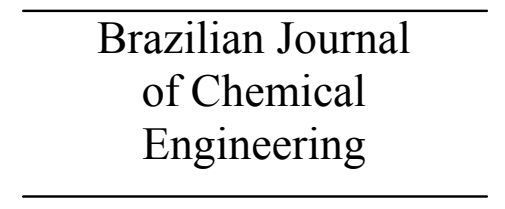

ISSN 0104-6632

Printed in Brazil

www.abeq.org.br/bjche

Vol. 29, No. 02, pp. 315 - 323, April - June, 2012

\title{
ALKALI-FREE METHOD OF HIDE PREPARATION FOR TANNING
}

\author{
V. Valeika ${ }^{1 *}, K$. Beleska $^{2}$ and J. Sirvaityte ${ }^{2}$ \\ ${ }^{1}$ Department of General Chemistry, Faculty of Chemical Technology, Kaunas University of Technology, \\ Phone: + 37037 300189, Fax: + 37037 300152, Radvilënų pl. 19, Kaunas LT-50254, Lithuania. \\ ${ }^{2}$ Department of Organic Technology, Faculty of Chemical Technology, Kaunas University of Technology, \\ Radvilènų pl. 19, Kaunas LT-50254, Lithuania. \\ E-mail: virgilijus.valeika@ktu.lt
}

(Submitted: February 20, 2011 ; Revised: October 24, 2011 ; Accepted: November 21, 2011)

\begin{abstract}
Usually, beamhouse processes are carried out by varying a medium from strongly alkaline (unhairing-liming) up to strongly acid (pickling). This study is designed to develop a preparation of hide for tanning via processes that avoid a sharp change of hide $\mathrm{pH}$. Enzymes active in acid medium are employed for hide unhairing in a buffer system containing $2.5 \%$ acetic acid and $0.3 \%$ sodium acetate. An oxidative treatment with peracetic acid then allows the complete removal of residual hair and scud. During both processes, unhairing and oxidative treatment, the opening of the derma structure occurs: 13.3-14.6g of noncollagen proteins are removed and amount of dermatan sulphate decreases by $35 \%$. The hide obtained can be chromed directly after the above processes and subsequent treatment with sodium chloride solution omitted conventional pickling. The $\mathrm{pH}$ of the hide varies in the range of 8.3-3.7 during the processes of preparation for tanning.

Keywords: Hide; Unhairing; Enzyme; Peracetic acid; Dermatan sulphate; Leather.
\end{abstract}

\section{INTRODUCTION}

An unhairing method that removes intact hairs is better than hair degradation methods from an environmental point of view due to less pollution of tannery wastewater by products of hair degradation and chemicals. Secondly, such a method decreases the process duration and saves the valuable raw material: hair. More and more often, various enzymes are used for intact hair removal (Foroughi et al., 2006; Priya et al., 2008; Sivasubramanian et al., 2008; Valeika et al., 2009; Dettmer et al., 2011). Usually, these enzymes are active in alkaline medium.

The use of enzymes for various leather manufacturing processes is very relevant, especially for developing environmentally clean technologies. The advantages of the use of enzymes for intact hair removal in comparison with hair degradation unhairing are as follows: shorter process duration, better opening of the derma structure, fast removal of dermatan sulphate (Madham et al., 2010), faster penetration of chromium and shorter chroming time (Saravanabhavan et al., 2003), and the leather obtained is softer and has a cleaner grain.

The main aim of unhairing with enzymes is to sufficiently weaken the bond of hair with derma by degrading the epidermis and ensuring the quality of the unhaired hide and the intact hairs (Crispim and Mota, 2003).

The problem is that, after enzymatic unhairing, some hair, scud, and epidermis always remain. Additional chemical materials must then be used to remove the mentioned residuals.

Previous investigations have shown that fresh hide can be unhaired by the hide's enzymes, which are activated by organic acid (Sivaparvathi et al., 1974; Sivaparvathi et al., 1979). This phenomenon appears while carrying out the unhairing process in

*To whom correspondence should be addressed 
acid medium and is named "autolytic unhairing". Unfortunately, only fresh hides and skins can be unhaired using "autolytic unhairing" because long term preservation fully inactivates hide enzymes.

The core of the present investigation was the processing of preserved and soaked hides, selecting enzymes that act as unhairing agents in acid medium. Further processes, such as oxidative removal of remaining hair, the opening up of the derma structure, and the preparation for chroming are also carried out in acid medium. Therefore, this approach to hide processing avoids the use of hazardous materials such as sodium sulphide mixed with large amounts of lime and ammonium salts.

The aim of this research was the development of leather processing in acid medium employing enzymes that are active as unhairing agents in such a medium and the estimation of the suitability of the method in conformity with the hide and leather properties after unhairing, removal of remaining hair and chroming.

\section{EXPERIMENTAL}

Salted cattle hide was used as the raw material. The samples for the investigation were taken from the lower part of the hide. The parameters of hide processing are presented in Table 1.

The soaked hide was cut into $5 \times 10 \mathrm{~cm}$ pieces and a series of samples was prepared from these pieces. One series contained 2 pieces from the lower (cattle rump) part, 2 pieces from the shoulder part, and 2 pieces from the belly part of hide. One series was used for each experiment. The pieces from the rump part were marked and, afterwards, used for determination of indexes such as amount of dermatan sulphate, shrinkage temperature, $\mathrm{pH}$, strength properties etc.

The processing of hide pieces was carried out using equipment that imitated the movement of hides in a drum, i.e., rolling vessels (volume of the vessel was 1 litre) with the hide samples. The rate of rolling was $20 \pm 1$ revolutions per minute.

Proteolytic enzyme preparations (EP) having high activity in weak acid medium, NovoBate WB (Novo Nordisk, Denmark) and Lithudac L (FGL International, Italy), were chosen as unhairing agents.

The removed collagen proteins were estimated from the amount of hydroxyproline in the alkaline solutions. The amount of hydroxyproline was determined by the photocolorimetric method (Golovtejeva et al., 1982).

Table 1: Parameters of hide processing.

\begin{tabular}{|c|c|c|c|}
\hline \multirow{2}{*}{ Process } & \multicolumn{3}{|l|}{ Process parameters } \\
\hline & Material and amount, $\%$ based on hide mass & Temperature, ${ }^{\circ} \mathbf{C}$ & Duration \\
\hline \multicolumn{4}{|c|}{ Experimental } \\
\hline Washing & $\mathrm{H}_{2} \mathrm{O}-200$ & $23-25$ & $1 \mathrm{~h}$ run continuously \\
\hline Soaking & $\mathrm{H}_{2} \mathrm{O}-200, \mathrm{Na}_{2} \mathrm{CO}_{3}-1.3$, EP Aquaderm $A-0.005$ & $23-25$ & $5 \mathrm{~h}$ run continuously \\
\hline Unhairing & $\begin{array}{l}\mathrm{H}_{2} \mathrm{O}-200 \text {, EP NovoBate WB or Lithudac } L-0.6, \mathrm{CH}_{3} \mathrm{COONa}-2.5 \text {, } \\
\mathrm{CH}_{3} \mathrm{COOH}-0.3\end{array}$ & $25-26$ & $5 \mathrm{~h}$ run continuously \\
\hline Washing & $\mathrm{H}_{2} \mathrm{O}-200$ & $23-25$ & $1 \mathrm{~h}$ run continuously \\
\hline $\begin{array}{l}\text { Oxidative } \\
\text { treatment }\end{array}$ & $\mathrm{H}_{2} \mathrm{O}-100, \mathrm{CH}_{3} \mathrm{C}(=\mathrm{O}) \mathrm{OOH}-3,0$ & $28-30$ & $3 \mathrm{~h}$ run continuously \\
\hline Washing & $\mathrm{H}_{2} \mathrm{O}-100$ & $18-20$ & 10 min run continuously \\
\hline $\begin{array}{l}\text { Treatment } \\
\text { with ammonia }\end{array}$ & $\mathrm{H}_{2} \mathrm{O}-30, \mathrm{NH}_{4} \mathrm{OH}-0.5$ & $18-20$ & 20 min run continuously \\
\hline Washing & $\mathrm{H}_{2} \mathrm{O}-100$ & $22-23$ & 10 min run continuously \\
\hline \multicolumn{4}{|c|}{ Control } \\
\hline Washing & $\mathrm{H}_{2} \mathrm{O}-200$ & $23-25$ & $1 \mathrm{~h}$ run continuously \\
\hline Soaking & $\mathrm{H}_{2} \mathrm{O}-200, \mathrm{Na}_{2} \mathrm{CO}_{3}(100 \%)-1.35$ & $23-25$ & $\begin{array}{l}1.5 \mathrm{~h} \text { run continuously; } \\
\text { later } 5 \mathrm{~min} \text {. every } 1 \mathrm{~h} \text {. } \\
\text { Total }-12 \mathrm{~h}\end{array}$ \\
\hline $\begin{array}{l}\text { Liming and } \\
\text { opening up of } \\
\text { derma } \\
\text { structure }\end{array}$ & $\begin{array}{l}\mathrm{H}_{2} \mathrm{O}-100, \mathrm{PAM}-0.1 ; \\
\mathrm{Ca}(\mathrm{OH})_{2}(100 \%)-2.3, \mathrm{Na}_{2} \mathrm{~S}(100 \%)-2 \\
\mathrm{Ca}(\mathrm{OH})_{2}(100 \%)-2.3 ; \\
\mathrm{H}_{2} \mathrm{O}-100\end{array}$ & $25-27$ & $\begin{array}{l}30 \text { min run continuously } \\
1.5 \mathrm{~h} \text { run continuously } \\
1 \mathrm{~h} \text { run continuously } \\
17 \mathrm{~h} \text { run continuously }\end{array}$ \\
\hline Washing & $\mathrm{H}_{2} \mathrm{O}-400$ & $25-27$ & $1 \mathrm{~h}$ run continuously \\
\hline $\begin{array}{l}\text { Deliming and } \\
\text { bating }\end{array}$ & $\begin{array}{l}\mathrm{H}_{2} \mathrm{O}-40,\left(\mathrm{NH}_{4}\right)_{2} \mathrm{SO}_{4}-2.2 ; \\
\left(\mathrm{NH}_{4}\right)_{2} \mathrm{SO}_{4}-2.2 ; \\
\text { EP Oropon ON2 }-0.15\end{array}$ & $35-37$ & $\begin{array}{l}0.5 \mathrm{~h} \text { run continuously } \\
0.5 \mathrm{~h} \text { run continuously } \\
1 \mathrm{~h} \text { run continuously }\end{array}$ \\
\hline Washing & $\mathrm{H}_{2} \mathrm{O}-200$ & $25-20$ & $0.5 \mathrm{~h}$ run continuously \\
\hline
\end{tabular}


The total amount of protein was estimated by employing Kjeldahl's method (Zaides et al., 1964). The amount of removed non-collagen proteins was calculated as the difference between the total proteins and the collagen proteins in the treatment solutions.

The EP proteolytic activity was determined by using the Anson method (Standard USSR, 1988). Sodium caseinate was used as substrate.

The $\mathrm{pH}$ of hide was determined according to a standard procedure (Standard ISO, 2008). The shrinkage temperature of hide (leather) was measured with a special instrument (Golovtejeva et al., 1982). The strength properties and amount of chrome compounds in leather were determined according to standard procedures (Standard ISO, 2002; Standard ISO, 2007).

The quality of unhairing was evaluated according to the following scoring system: $0-$ the bond between hair and derma is not weakened; 1 - the bond between hair and derma is weakened marginally; 2 - the bond between hair and derma is weakened markedly, but mechanical removal of hair from derma is not easy; 3 hair can be completely removed mechanically.

The content of dermatan sulphate in the hide was determined by using the modified method of Gibbons and Wolfrom (Kazlauskaite et al., 2002). After removing soluble sulphates using distilled water and drying to absolute dryness, the samples were ashed at $600-700^{\circ} \mathrm{C}$. The ash was dissolved and determination of sulphate sulphur was carried out.

Samples of hide chosen for IR-spectroscopic analysis were split to obtain a $0.9-1.0 \mathrm{~mm}$ width of the upper layer. The samples for the IRspectroscopic analyses were prepared as pellets using $200 \mathrm{mg}$ of optically pure $\mathrm{KBr}$ and $2 \mathrm{mg}$ of hide tissue, which was taken from the surface formed after splitting. An infrared reflection spectrum was obtained using a Perkin-Elmer FTIR Spectrum GX (USA) spectrometer. The resolution was $1 \mathrm{~cm}^{-1}$, scan rate $0.2 \mathrm{~cm} / \mathrm{s}$ and scan number 16 times. The software "Spectrum 5.0.1" was used for calculation of the area of the peaks in the spectra $\Delta S\left(\mathrm{~T} \% \cdot \mathrm{cm}^{-1}\right)$.

\section{RESULTS AND DISCUSSION}

\section{Enzymatic Unhairing of Hide}

Fresh and short term preserved hides can be unhaired and further processed without sodium sulphide and alkali (Sivaparvathi et al., 1979). Unfortunately, this method can not be applied to preserved hides as the "autolytic unhairing" does not occur for preserved hide. During preliminary investigation, two proteolytic EP: NovoBate WB (Novo Nordisk, Denmark) isolated from Bacillus microorganisms and Lithudac L (FGL International, Italy) isolated from Aspergillus flavus, were chosen for further experiments because these EP had shown evident unhairing ability in acid medium. Commonly, the mentioned EP are adapted for re-bating of leather (wet-blue) after chroming, but not as unhairing agents.

It was established that acetic acid, which is used in the unhairing process, not only activates hide enzymes but also removes affected components of hide (Balciuniene et al., 1994). Due to this, the enzymatic unhairing should occur more intensively using acetic acid in the process medium compared with other acids.

Because the enzymes had higher activity in a particular $\mathrm{pH}$ range, pure acetic acid was replaced by unhairing buffer system (UBS) having a $\mathrm{pH}$ 5.4-5.5 and containing acetic acid, sodium acetate and EP.

In order to reduce the amount of wastewater, it is advisable to carry out unhairing directly after soaking (after draining of soaking solution, but without washing). The $\mathrm{pH}$ of the soaking solution is 9.9 and the $\mathrm{pH}$ of the hide after soaking is 8.7-8.8.

First, investigations seeking to establish the suitable amount of EP, acetic acid and sodium acetate for qualitative weakening of the bond between the hair and derma were carried out. The results obtained are presented in Table 2.

Based on these results, it can be supposed that the amount of EP required to unhair is $0.6 \%$; the buffer solution should consist of $2.5 \% \mathrm{CH}_{3} \mathrm{COONa}$ and $0.3 \% \mathrm{CH}_{3} \mathrm{COOH}$ (\% based on hide mass), and the duration of the process should be not shorter than $3 \mathrm{~h}$.

Secondly, a comparative investigation of the $\mathrm{pH}$ change kinetics of unhairing solutions (water with enzyme or UBS) was carried out (Fig. 1). This showed that the $\mathrm{pH}$ increases up to $8.7-8.8$ (Fig. 1, (a)) when unhairing with an aqueous solution of enzyme was carried out for $0.5 \mathrm{~h}$. This can be explained by diffusion of alkaline materials from the soaked hide into solution. On the other hand, the degradation of soft keratin, which is present in the roots of hair, by enzymes begins and products of its degradation (amino acids) slowly decrease the $\mathrm{pH}$ to 8.5 during the second $3 \mathrm{~h}$. After that, the equilibrium is reached and the $\mathrm{pH}$ of medium does not change.

Using UBS the value of the $\mathrm{pH}$ rises from 5.5 up to 6.2 during the first hour (Fig. 1, (b)). During the second 4 hours, the $\mathrm{pH}$ changes up to 6.9 and, after that, remains unchanged. Since an investigation of EP activity showed that EP NovoBate $W B$ and Lithudac $L$ have higher activity in the range of $\mathrm{pH}$ 6.1-7.2 (Fig. 2), this means that acetate buffer is very suitable for action of these EP. 
Table 2: Results of preliminary investigation of unhairing.

\begin{tabular}{|c|c|c|c|c|c|c|c|}
\hline \multirow{2}{*}{$\begin{array}{l}\text { Variant } \\
\text { number }\end{array}$} & \multicolumn{4}{|c|}{ Amount of material, \% based on hide mass } & \multicolumn{2}{|c|}{ pH of solution } & \multirow{2}{*}{$\begin{array}{c}\text { Unhairing quality, } \\
\text { points }\end{array}$} \\
\hline & NovoBate $\mathrm{WB}$ & Lithudac L & $\mathrm{CH}_{3} \mathrm{COONa}$ & $\mathrm{CH}_{3} \mathrm{COOH}$ & initial & after $3 \mathrm{~h}$ & \\
\hline 1 & 0.05 & - & 16 & 3 & 5.32 & 5.32 & 0 \\
\hline 2 & 0.6 & - & 16 & 3 & 5.32 & 5.31 & 0 \\
\hline 3 & 0.05 & - & 2.5 & 0.3 & 5.34 & 6.40 & 0 \\
\hline 4 & 0.6 & - & 2.5 & 0.3 & 5.34 & 6.68 & $2-3$ \\
\hline 5 & 0.3 & - & 2.5 & 0.3 & 5.34 & 6.70 & 3 \\
\hline 6 & 0.6 & - & - & 0.3 & 2.98 & 6.18 & 0 \\
\hline 7 & 0.6 & - & 4.0 & 0.5 & 5.45 & 6.16 & 3 \\
\hline 8 & - & 0.05 & 2.5 & 0.3 & 5.34 & 6.73 & 0 \\
\hline 9 & - & 0.1 & 2.5 & 0.3 & 5.34 & 6.39 & 0 \\
\hline 10 & - & 0.3 & 2.5 & 0.3 & 5.34 & 6.77 & 2 \\
\hline 11 & - & 0.6 & 2.5 & 0.3 & 5.34 & 6.39 & 3 \\
\hline 12 & - & 0.6 & 4.0 & 0.5 & 5.42 & 6.14 & $2-3$ \\
\hline 13 & - & 0.6 & 16.5 & 2 & 5.59 & 5.68 & 2 \\
\hline 14 & - & 0.6 & - & 0.5 & 2.88 & 5.03 & 0 \\
\hline
\end{tabular}

Note. Amount of $\mathrm{H}_{2} \mathrm{O}$ in all cases $100 \%$ based on hide mass, temperature $-36-37^{\circ} \mathrm{C}$.

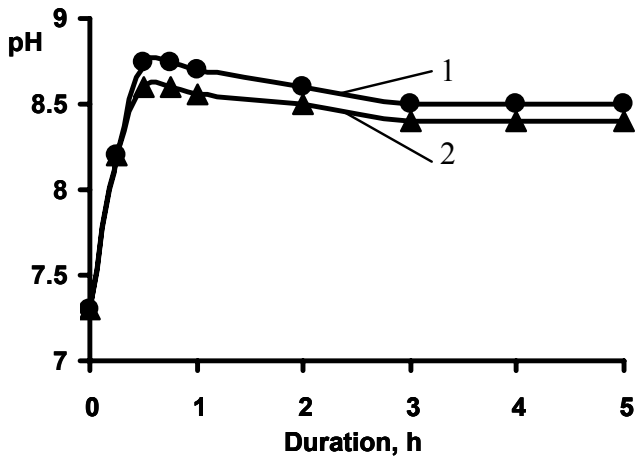

(a)

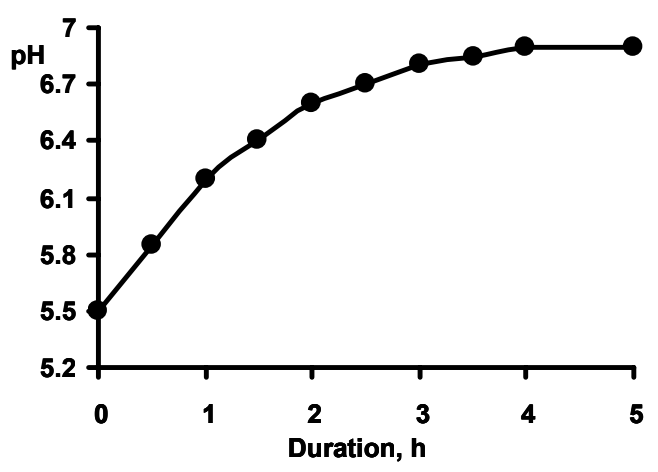

(b)

Figure 1: Alternation of unhairing solution $\mathrm{pH}$ during the unhairing process: (a) - unhairing carried out using water solutions of $0.6 \%$ EP NovoBate WB (1) or $0.6 \%$ EP Lithudac L (2); (b) - unhairing carried out using $0.6 \%$ solution of EP NovoBate WB in acetate buffer.

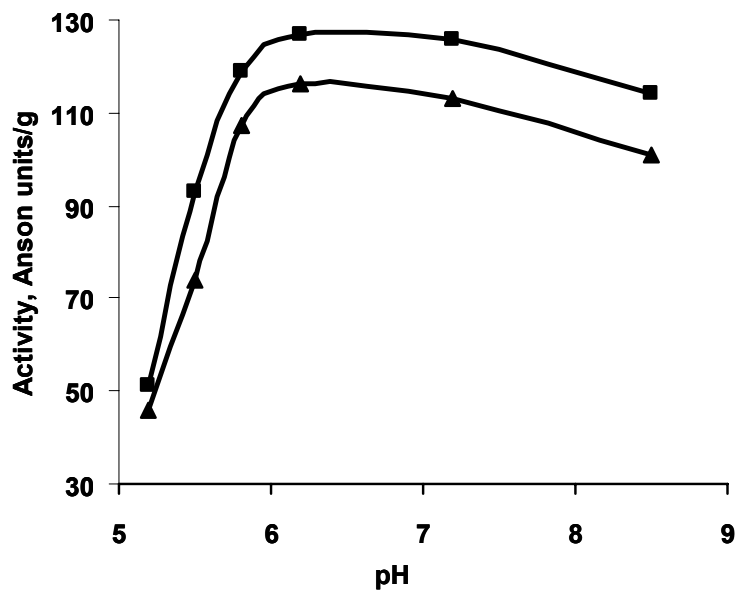

Figure 2: Dependence of EP (1- NovoBate WB, 2 Lithudac L) activity on $\mathrm{pH}$ of the substrate solution (temperature $30^{\circ} \mathrm{C}$; duration of action $10 \mathrm{~min}$ ). 
The unhairing using UBS was carried out under the conditions described in Table 1. The amount of removed collagenous and total proteins was determined, and the $\mathrm{pH}$ of the solution was measured. The quality of unhairing was evaluated by attributing points. Also, the influence of temperature on the process was established. The results obtained are presented in Table 3.

Results show that, when NovoBate WB or Lithudac $L$ is used, the bond between hair and derma is completely broken and the structure of the derma is somewhat opened up. Obviously, temperature has an influence on the changes in the derma structure. The increase of the process temperature increases the amount of proteins removed. On the other hand, too high a degradation and removal of collagenous proteins during unhairing is undesirable, as this can cause defects in the leather produced. It is known that, during unhairing and opening up of the derma structure, $0.5-0.6 \mathrm{~g} / \mathrm{kg}$ of hide collagenous and $10 \mathrm{~g} / \mathrm{kg}$ of hide total proteins are usually removed (Valeika et al., 2000). This means that unhairing should be carried out at $20-25^{\circ} \mathrm{C}$, but the process should be prolonged up to $5 \mathrm{~h}$. Jian et al. (2011) report that further prolongation of the unhairing process by proteases is not desirable due to possible serious injury of collagen.

The $\mathrm{pH}$ of the UBS solution remains suitable for high activity of EP during 24 hours.

It can be concluded that qualitative unhairing of hides can be carried out using UBS containing $0.6 \%$ (based on hide mass) EP NovoBate WB or Lithudac L, with a temperature of $20-25^{\circ} \mathrm{C}$ and process duration of $5 \mathrm{~h}$.

Changes of Proteins, Dermatan Sulphate, Shrinkage Temperature, and pH of Hide During Unhairing and Oxidative Treatment

The principal problem of enzymatic unhairing is always that, after the process and mechanical removal of hair, the scud and some hair remain on the hide. There are several ways to solve this problem. The first one includes the use of sulphides. However, the amount of sulphides usually used is so large that enzymatic unhairing no longer makes any sense, as the enzymes are being used precisely as an alternative to sulphide unhairing. Due to this, an oxidative treatment using peracetic acid was chosen for the final degradation of the remaining hair and opening up of the derma in this case. Carried out under the conditions described in Table 1, the oxidative treatment consisted of two processes: oxidation of keratin containing epidermis and hair with peracetic acid; and subsequent dissolving of oxidized hair and epidermis by alkali. After oxidation with peracetic acid, a small amount of weak alkali (ammonia in this case) is sufficient for final degradation of hair and epidermis residues and does not change the $\mathrm{pH}$ of hide noticeably.

The properties of hide obtained by enzymatic unhairing and subsequent oxidative treatment have been investigated and compared with conventionally processed hide properties (Table 4).

The investigation of the change in the amount of dermatan sulphate has shown that removal of dermatan sulphate is intensive. Also, the removal of dermatan sulphate from hide occurred during oxidative treatment and the amount of dermatan sulphate that remained in the hide depended on the enzymatic preparation used. The shrinkage temperature of hide after unhairing and oxidative treatment was $8.0-9.0^{\circ} \mathrm{C}$ lower compared to soaked hide. All results show that an effective opening up of the derma structure takes place during hide processing. Also, the grain of hide after oxidative treatment was completely clean.

The changes of hide $\mathrm{pH}$ are presented in Fig. 3.

The data (Fig. 3) show that hide $\mathrm{pH}$ changed in a smaller interval and the changes of $\mathrm{pH}$ were less when the processes were carried out according to the proposed technology as compared to the conventional one.

Table 3: Influence of temperature on the unhairing process.

\begin{tabular}{|c|c|c|c|c|c|c|c|}
\hline \multirow{3}{*}{$\begin{array}{l}\text { Temperature, } \\
{ }^{\circ} \mathrm{C}\end{array}$} & \multirow{3}{*}{ EP } & \multicolumn{2}{|c|}{$\begin{array}{l}\text { Removed non-collagen } \\
\text { proteins, } \mathrm{g} / \mathrm{kg} \text { of hide }\end{array}$} & \multicolumn{2}{|c|}{$\begin{array}{l}\text { Removed collagenous } \\
\text { proteins, g/kg of hide }\end{array}$} & \multicolumn{2}{|c|}{$\begin{array}{c}\text { Unhairing quality, } \\
\text { points }\end{array}$} \\
\hline & & \multicolumn{6}{|c|}{ When unhairing duration is, $h$} \\
\hline & & 5 & 24 & 5 & 24 & 5 & 24 \\
\hline \multirow{2}{*}{20} & NovoBate $W B$ & 4.58 & 6.58 & 0.09 & 0.16 & 3 & 3 \\
\hline & Lithudac L & 4.61 & 6.50 & 0.08 & 0.16 & $2-3$ & 3 \\
\hline \multirow{2}{*}{25} & NovoBate $W B$ & 5.13 & 7.55 & 0.11 & 0.21 & 3 & 3 \\
\hline & Lithudac L & 5.84 & 7.69 & 0.09 & 0.2 & $2-3$ & 3 \\
\hline \multirow{2}{*}{30} & NovoBate $W B$ & 5.19 & 8.34 & 0.16 & 0.33 & 3 & 3 \\
\hline & Lithudac L & 6.81 & 9.59 & 0.15 & 0.32 & 3 & 3 \\
\hline \multirow{2}{*}{37} & NovoBate $W B$ & 5.85 & 8.36 & 0.21 & 0.50 & 3 & 3 \\
\hline & Lithudac L & 6.95 & 10.82 & 0.22 & 0.51 & 3 & 3 \\
\hline
\end{tabular}


Table 4: Influence of beamhouse processes on hide properties prepared for tanning.

\begin{tabular}{|c|c|c|c|c|c|}
\hline \multirow{4}{*}{ Index } & \multicolumn{5}{|c|}{ Process } \\
\hline & \multirow{3}{*}{ Soaking } & \multicolumn{2}{|c|}{ Unhairing } & \multicolumn{2}{|c|}{ Oxidative treatment } \\
\hline & & \multicolumn{4}{|c|}{ EP used for unhairing } \\
\hline & & NovoBate WB & Lithudac L & NovoBate $\mathrm{WB}$ & Lithudac L \\
\hline $\begin{array}{l}\text { Removed collagenous proteins, } \\
\mathrm{g} / \mathrm{kg} \text { of hide }\end{array}$ & 0.09 & 0.16 & 0.12 & 0.17 & 0.20 \\
\hline $\begin{array}{l}\text { Removed non-collagen proteins, } \\
\mathrm{g} / \mathrm{kg} \text { of hide }\end{array}$ & 3.13 & 9.52 & 10.81 & 3.79 & 3.78 \\
\hline $\begin{array}{l}\text { Dermatan sulphate content in hide, } \\
\% \text { of dry collagen mass }\end{array}$ & 0.46 & 0.37 & 0.35 & 0.31 & 0.30 \\
\hline $\begin{array}{l}\text { Shrinkage temperature, } \\
{ }^{\circ} \mathrm{C}\end{array}$ & 65.1 & 66.7 & 68.0 & 55.7 & 56.5 \\
\hline
\end{tabular}

Note. During conventional beamhouse processes $24.2 \mathrm{~g} / \mathrm{kg}$ of hide non-collagen and $0.49 \mathrm{~g} / \mathrm{kg}$ of hide collagenous proteins were removed; dermatan sulphate content in hide after these processes was $0.24-0.37 \%$ based on dry collagen mass; shrinkage temperature changed from $65-66$ to $55-56^{\circ} \mathrm{C}$.

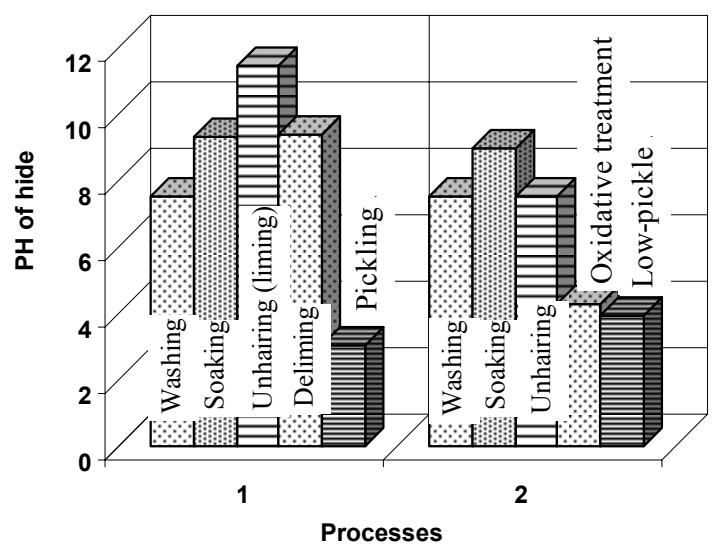

Figure 3: The $\mathrm{pH}$ of hide after the processes: 1 - control hide; 2 - experimental.

\section{Investigation of Unhaired Hide Structure}

The evaluation of hide structural changes was carried out by IR-spectroscopy, recording reflection spectra of hide (Fig. 4) in the range of $4000-800 \mathrm{~cm}^{-1}$. IR-spectra were recorded for the sample and control hides after the processes described in Table 1. IRspectra were analysed using the software Spectrum v5.0.1. and the area of peaks $\left(\Delta \mathrm{T}, \% \mathrm{~T} \cdot \mathrm{cm}^{-1}\right)$ calculated. Comparison of peak areas allows conclusions about the formation of functional groups and degradation or formation of bonds during leather processing. The results are presented in Table 5.

The data in Table 5 show differences between the areas of peaks in the ranges of $3270-3283 \mathrm{~cm}^{-1}$ and 2916-2921 $\mathrm{cm}^{-1}$. The vibrations in the range of $3300-2500 \mathrm{~cm}^{-1}$ are attributed to the functional groups $\mathrm{O}-\mathrm{H}, \mathrm{N}-\mathrm{H}$ and $\mathrm{C}-\mathrm{H}$. The experimental hide's peak area is about 1.6 time bigger than the control. This shows that the processing of experimental hide breaks fewer hydrogen bonds. Due to this, we have a more stable system compared to the control hide. The evaluation of the removal of interfiber and collagen proteins (Table 3 ) proves this supposition: a smaller amount of interfiber and collagen proteins is degraded during processing of the experimental hide.

In the IR spectra of carboxylic acids, the peaks are in the range of $1760-1720 \mathrm{~cm}^{-1}$; the peak of the deformation vibration of $\mathrm{C}-\mathrm{O}-\mathrm{H}$ is in the range of $1440-1395 \mathrm{~cm}^{-1}$ and the peak of $\mathrm{C}-\mathrm{O}$ valence vibration is in the range of $1320-1210 \mathrm{~cm}^{-1}$ (Buika et al., 2007). In the carboxylate anion, there are two peaks: an intense peak for the valence vibration in the range of 1650 $1550 \mathrm{~cm}^{-1}$ and a weak peak for the symmetric valence vibration at $\sim 1400 \mathrm{~cm}^{-1}$. Such peaks allow using the changes in spectra for identifying carboxylic acids.

Investigating derma proteins, the amount of carboxyl groups reflects the ongoing situation. The data in Table 4 show that peak areas in experimental hide spectra $\left(1738-1740 \mathrm{~cm}^{-1}\right.$ and $\left.1724-1726 \mathrm{~cm}^{-1}\right)$ are about 3.6 times bigger than the control. It is known that the amount of carboxyl groups depends on hide $\mathrm{pH}$ : the amount decreases with increasing $\mathrm{pH}$ of the hide and vice versa (Bienkewicz, 1983). The $\mathrm{pH}$ of experimental hide was 4.3 and of the control was 9.4. These values of $\mathrm{pH}$ determine the amount of ionized carboxyl groups in collagen and, correspondingly, the areas of the peaks. 


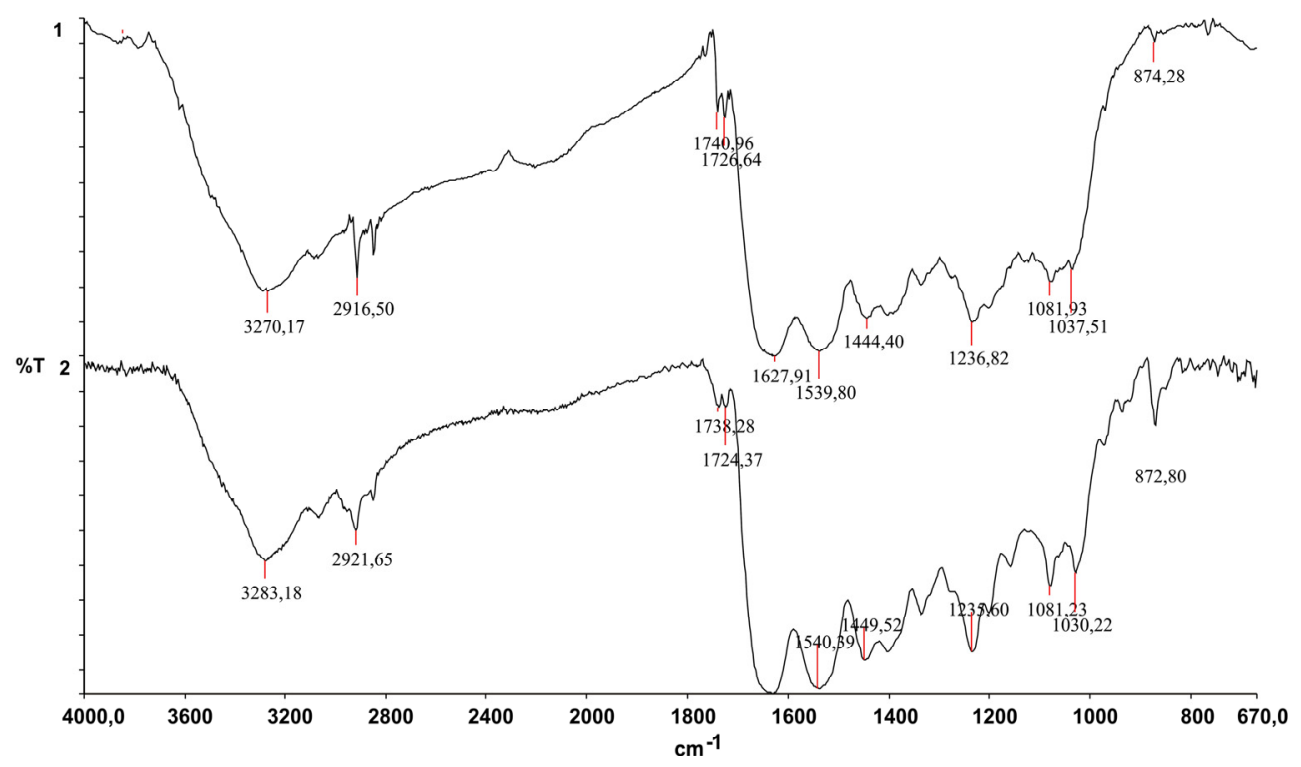

Figure 4: IR-spectra of hide prepared for tanning. 1 - experimental; 2 - control.

Table 5: Data of IR-spectrum quantitative analysis.

\begin{tabular}{|c|c|c|c|c|}
\hline \multirow{3}{*}{$\begin{array}{l}\text { Functional group or bond, to } \\
\text { which the wibration is attributed }\end{array}$} & \multicolumn{4}{|c|}{ Hide } \\
\hline & \multicolumn{2}{|c|}{ Experimental } & \multicolumn{2}{|c|}{ Control } \\
\hline & $v, \mathrm{~cm}^{-1}$ & $\Delta \mathrm{T}, \% \mathrm{~T} \cdot \mathrm{cm}^{-1}$ & $\mathrm{v}, \mathrm{cm}^{-1}$ & $\Delta \mathrm{T}, \% \mathrm{~T} \cdot \mathrm{cm}^{-1}$ \\
\hline $\mathrm{O}-\mathrm{H} ; \mathrm{N}-\mathrm{H}$ & 3276 & 18709 & 3283 & 11598 \\
\hline $\mathrm{C}-\mathrm{H}$ & 2916 & 810 & 2921 & 1166 \\
\hline $\mathrm{C}-\mathrm{H}$ & 1740 & 88 & 1738 & 24 \\
\hline $\mathrm{R}-\mathrm{COO}^{-}$ & 1726 & 18 & 1724 & 5 \\
\hline $\begin{array}{l}=\mathrm{C}=\mathrm{O} \\
\text { "amide band I" }\end{array}$ & 1627 & 3332 & 1629 & 4080 \\
\hline $\begin{array}{l}\mathrm{N}-\mathrm{H} \\
\text { "amide band II" }\end{array}$ & 1539 & 1048 & 1540 & 1313 \\
\hline $\mathrm{C}-\mathrm{O}$ & 1444 & 199 & 1449 & 336 \\
\hline $\begin{array}{l}\mathrm{N}-\mathrm{H} \\
\text { "amide band III" }\end{array}$ & 1236 & 332 & 1235 & 426 \\
\hline $\begin{array}{l}\left(\mathrm{SO}_{4}\right)^{2-} ; \mathrm{R}-\mathrm{SO}_{3}{ }^{-} ; \\
\mathrm{R}-\mathrm{SO}_{3} \mathrm{H}\end{array}$ & $\begin{array}{l}1081 \\
1037\end{array}$ & $\begin{array}{r}102 \\
47\end{array}$ & $\begin{array}{l}1081 \\
1030\end{array}$ & $\begin{array}{l}174 \\
188\end{array}$ \\
\hline $\mathrm{Ca}-\mathrm{O} ; \mathrm{C}-\mathrm{N}$ & 874 & 14 & 872 & 169 \\
\hline
\end{tabular}

Peaks in the ranges of $1627-1629 \mathrm{~cm}^{-1}, 1539$ $1540 \mathrm{~cm}^{-1}$ and $1235-1236 \mathrm{~cm}^{-1}$ are attributed to deformation vibrations of $\mathrm{N}-\mathrm{H}$ (respectively I, II and III amide bands). The areas of the peaks in these ranges are similar and thus indicate similar changes of hide structure during beam house processes. The results (Table 3 ) of investigation of removed interfiber and collagen proteins, dermatan sulphate, and shrinkage temperature prove this supposition.

Very big differences (about 11-fold) between the areas of peaks in the experimental and control hide were observed in the range of $872-874 \mathrm{~cm}^{-1}$. This difference appears to be due to $\mathrm{Ca}-\mathrm{O}$ in control hide, because this hide was obtained using $\mathrm{Ca}(\mathrm{OH})_{2}$, while the experimental one was processed without $\mathrm{Ca}(\mathrm{OH})_{2}$. It is known that, when using $\mathrm{Ca}(\mathrm{OH})_{2}$ for unhairing and opening up of derma, part of the Ca binds to carboxyl groups of derma and is not removed in the deliming process.

According to data in the literature, peaks at $1081 \mathrm{~cm}^{-1}$ and $1030 \mathrm{~cm}^{-1}$ are specific to collagen (Bienkewicz, 1983). Unfortunately, it is not clear what groups absorb in these ranges. There is an opinion that these vibrations are specific to the sulpho group. The data in Table 5 show that the area of peaks of experimental hide in the mentioned range is about 4 times lower than for the control. The 
increase of sulpho groups in the control hide is due to the $\left(\mathrm{NH}_{4}\right)_{2} \mathrm{SO}_{4}$ used in deliming.

Therefore, the IR-spectroscopic analysis confirms the results of chemical and physical analyses of hide: the hide obtained according to the experimental technology has properties very close to hide processed using conventional one.

\section{Properties of Chromed Leather}

In order to establish the workability of the unhairing and oxidative treatment methods for leather processing, the properties of chromed leather were evaluated.

As shown by previous investigation, a hide after treatment with peracetic acid and bating could be directly chromed, omitting pickling, or chromed after treatment with $\mathrm{NaCl}$ solution (low-pickle) instead of conventional pickling (Sirvaityte et al., 2009).

Due to this, before chroming the hide was treated under the following conditions ( $\%$ based on hide mass): $\mathrm{H}_{2} \mathrm{O} 40 \%, \mathrm{NaCl} 6.5 \%$, temperature $20-22^{\circ} \mathrm{C}$, duration $2 \mathrm{~h}$, run continuously. The chroming was carried out in the solution of the previous treatment and the parameters of chroming were $(\%$ based on hide mass): $\mathrm{H}_{2} \mathrm{O} \quad 40 \%, \mathrm{Cr}_{2} \mathrm{O}_{3} \quad 1.5 \%$ (basicity of chromium extract $20 \%$ ), temperature $20-22^{\circ} \mathrm{C}$, duration $12 \mathrm{~h}$; Neutragene MG-120 (material for increasing basicity) $0.25 \%$, duration $2 \mathrm{~h}$; Neutragene $M G-1200.25 \%$, duration $2 \mathrm{~h}$; Neutragene $M G-120$ $0.25 \%$, duration $2 \mathrm{~h} ; \mathrm{H}_{2} \mathrm{O} 40 \%$, temperature $60^{\circ} \mathrm{C}$, duration $1 \mathrm{~h}$, all run continuously.

The analysis of chromed leather was performed and the results obtained are presented in Table 6 .

Table 6: Qualitative indexes of chromed leather.

\begin{tabular}{|r|c|}
\hline Index & Value \\
\hline Shrinkage temperature of leather, ${ }^{\circ} \mathrm{C}$ & 105 \\
\hline Amount of $\mathrm{Cr}_{2} \mathrm{O}_{3}$ in leather, \%, & 3.37 \\
and in separate layers: & \\
upper & 3.85 \\
middle & 2.85 \\
flesh & 3.39 \\
Tensile strength of leather, $\mathrm{N} / \mathrm{mm}^{2}$ & 15.8 \\
Grain strength at break, $\mathrm{N} / \mathrm{mm}^{2}$ & 14.5 \\
\hline Relative elongation of leather, \% & 83 \\
\hline
\end{tabular}

Note. The chromed samples were split at a thickness of $2 \mathrm{~mm}$ of upper layer and strength indexes established. Relative elongation was measured when the strain of $10 \mathrm{~N} / \mathrm{mm}^{2}$ was reached.

The results show good quality of chroming because the shrinkage temperature exceeds $100^{\circ} \mathrm{C}$; the distribution of chromium in the layers of leather is even enough. The strength properties of the leather are not impaired when compared with the figures corresponding to normal production leather (Zhou et al., 2011; Bacardit et al., 2009).

\section{CONCLUSIONS}

Washed and soaked hide can be qualitatively unhaired using an unhairing buffer system containing acetic acid, sodium acetate, and the enzyme preparations NovoBate WB (Denmark) or Lithudac L (Italy) active in acid medium. The acetate buffer should have $\mathrm{pH}$ 5.4-5.5. The amount of EP NovoBate $W B$ or Lithudac $L$ in acetate buffer for unhairing should be $0.6 \%$ (based on hide mass) EP and the process should be carried out at $20-25^{\circ} \mathrm{C}$ for 5-6 h.

The residual hair and scud can be removed completely with peracetic acid. The influence of the enzymatic preparations NovoBate WB and Lithudac $L$ on noncollagen and collagenous proteins is similar during both the unhairing and oxidative treatment. Dermatan sulphate analysis has shown that removal of dermatan sulphate is intensive. All results show that an effective opening up of derma structure occurs during the hide processing.

After enzymatic unhairing and oxidative treatment, the hide can be prepared for chroming by replacing conventional pickling with treatment with $\mathrm{NaCl}$ solution.

Leather processing in acid medium avoids the use of sodium sulphide and decreases significantly the demand for ammonium salts and chromed leather with good shrinkage and strength properties is produced.

\section{REFERENCES}

Bacardit, A., Olle, L., Morera, J., Bartoli, E., Palomares, H. and Borras, D., Lower pollution pickle-chrome process: a no-float/low-salt approach. Journal of the Society of Leather Technologists and Chemists, 93, No. 2, 67 (2009).

Balciuniene, J., Beleska, K., Skrodenis, A., Valeika, V. and Valeikiene, V., Sochrannost I razrychlenye dermy shkur pri avtoliticheskom obezvolachivanyi. Kozhevenno-obuvnaiya Promyshlennost, No. 11, 23, (1994). (In Russian).

Bienkewicz, K., Physical chemistry of leather making. Robert E. Krieger Publishing Co. Inc., Malabar, Florida (1983).

Buika, G., Getautis, V., Martynaitis, V. and Rutkauskas K., Spectroscopy of organic compounds. 
Vitae Litera, Kaunas, Lithuania (2007). (In Lithuanian).

Crispim, A. and Mota, M., Unhairing with enzymes. Journal of the Society of Leather Technologists and Chemists, 87, No. 5, 198 (2003).

Dettmer, A., Ayub, M. A. Z., and Gutterres, M., Hide unhairing and characterization of commercial enzymes used in leather manufacture. Brazilian Journal of Chemical Engineering, 28, No. 3, 373 (2011).

Foroughi, F., Keshavarz, T. and Evans, C. S., Specificities of proteases for use in leather manufacture. Journal of Chemical Technology and Biotechnology, 81, No. 3, 257 (2006).

Golovtejeva, A., Kucidi, D. and Sankin, L., Laboratornyi praktikum po technologyi kozhi i mecha. Legkayia I Pischevayia Promyshlenost, Moscow, USSR (1982). (In Russian).

Jian, S., Wenyi, T. and Wuyong, C., Kinetics of enzymatic unhairing by protease in leather industry. Journal of Cleaner Production, 19, No. 4 (2011).

Kazlauskaite, E., Balciuniene, J., Zaliauskiene, A., Beleska, K., Valeika V. and Valeikiene V., Influence of unhairing method on dermatan sulphate and microscopical investigation of pelt and leather. Journal of the Society of Leather Technologists and Chemists, 86, No. 2, 59 (2002).

Madham, B., Dineshkumar, M., Rao, J. R. and Nair, B. U., Studies on the removal of inter-fibrillary materials. Part II: Removal of protein, proteoglycan and glycosoaminoglykans from biobased pre-tanning process. Journal of American Leather Chemists Association, 105, No 6, 181 (2010).

Priya, S., Rajaram, A., Rajaram, R. and Ramasami, T., Depilation of skins by pure enzymes. Journal of the Society of Leather Technologists and Chemists, 92, No. 5, 214 (2008).

Saravanabhavan, S., Aravindham, R., Thanikaivelan, P., Rao, J. R. and Nair, B. U., Green solution for tannery pollution: effect of enzyme based limefree unhairing and fibre opening in combination with pickle-free chrome tanning. Green Chemistry, 5, No 6, 707 (2003).

Sirvaityte, J., Valeika, V. and Plavan, V., Peracetic acid deliming. Part II: Pickle-free and low-pickle processing of peracetic acid delimed pelt. Journal of Society of Leather Technologists and Chemists, 93, No. 2, 40 (2009).

Sivaparvathi, M., Nandy, S. C. and Dhar S. C., Effect of various factors on the autolitic enzymatic unhairing of skin. Leather Science, 21, No. 9, 297 (1974).

Sivaparvathi, M., Nandy, S. C. and Santappa, M., Die Funktion der sauren Proteasen der Haut bei der Entharung. Das Leder, No. 6, 97 (1979). (In German).

Sivasubramanian, S., Manohar, B. M., Rajaram, A. and Puvanakrishnan, R., Ecofriendly lime and sulfide free enzymatic dehairing of skins and hides using a bacterial alkaline protease. Chemosphere, 70, No. 6, 1015 (2008).

Standard ISO 4045:2008. Leather - Chemical tests Determination of $\mathrm{pH}$.

Standard ISO 3376:2002. Leather - Physical and mechanical tests - Determination of tensile strength and percentage extension.

Standard ISO 5398-1:2007, Leather - Chemical determination of chromic oxide content - Part 1: Quantification by titration.

Standard USSR: GOST 20264-88. Enzyme preparations - Methods of determination of proteolytic activity.

Valeika, V., Balciuniene, J., Beleska, K. and Valeikiene, V., Lime-free unhairing: Part 3. Influence of unhairing method on chemical, physical and mechanical properties of pelt and leather. Journal of Society of Leather Technologists and Chemists, 84, No. 4, 165 (2000).

Valeika, V., Beleska, K., Valeikiene V. and Kolodzeiskis, V., An approach to cleaner production: from hair burning to hair saving using a lime-free unhairing system. Journal of Cleaner Production, 17, No. 2, 214 (2009).

Wang, R., Min, C., Haiming, C. and Li, Z. Q., Enzyme unhairing - an eco-friendly biotechnological process. Journal of the Society of Leather Technologists and Chemists, 93, No. 2, 51 (2009).

Zaides, A., Mikhailov, A. and Pushenko O., Modiphitsirovanyi method opredeleniya oksiprolina. Biokhimiya, No. 1, 5 (1964). (In Russian).

Zhou, P., Xuepin, L. and Bi, S., Preparation of lignosulfonate Reduced Chrome Tanning Agent and its Tanning Effect. Journal of the Society of Leather Technologists and Chemists, 95, No. 4, 158 (2011). 